\title{
Expression of polo-like kinase 1 in pre-implantation stage murine somatic cell nuclear transfer embryos
}

\author{
Jeonghyeon Moon, Sangho Roh* \\ Cellular Reprogramming and Embryo Biotechnology Laboratory, Dental Research Institute, BK21 PLUS Dental Life Science, Seoul National University \\ School of Dentistry, Seoul 08826, Korea
}

\begin{abstract}
Somatic cell nuclear transfer (SCNT) has various applications in research, as well as in the medical field and animal husbandry. However, the efficiency of SCNT is low and the accurate mechanism of SCNT in murine embryo development is unreported. In general, the developmental rate of SCNT murine embryos is lower than in vivo counterparts. In previous studies, polo-like kinase 1 (Plk1) was reported to be a crucial element in cell division including centrosome maturation, cytokinesis, and spindle formation. In an initial series of experiments in this study, BI2536, a Plk1 inhibitor, was treated to in vivo-fertilized embryos and the embryos failed to develop beyond the 2-cell stage. This confirmed previous findings that Plk1 is crucial for the first mitotic division of murine embryos. Next, we investigated Plk1's localization and intensity by immunofluorescence analysis. In contrast to normally developed embryos, SCNT murine embryos that failed to develop exhibited two types of Plk1 expressions; a low Plk1 expression pattern and ectopic expression of Plk1. The results show that Plk1 has a critical role in SCNT murine embryos. In conclusion, this study demonstrated that the SCNT murine embryos fail to develop beyond the 2-cell stage, and the embryos show abnormal Plk1 expression patterns, which may one of the main causes of developmental failure of early SCNT murine embryos.
\end{abstract}

Keywords: Polo-like kinase 1; Somatic cell nuclear transfer technique; Development; Cell division; Embryo

\section{Introduction}

Creation of an embryo via the somatic cell nuclear transfer (SCNT) method has various potential applications such as species conservation [21], regenerative medicine [10], and animal husbandry [38]. After the initial production of the cloned sheep 'Dolly' by Campbell et al. [7], cloned animals were developed by applying SCNT in 23 mammalian species including mouse [37], bovine [15], pig [3], and primate [6,8]. However, the use of SCNT has several problems. Above all, low efficiency is the biggest obstacle in the application of SCNT [17]. Many previous studies have shown success in inducing developmental rate improvement by using chemicals $[13,35]$, vitamins [22], and histone modifiers [5,11]. Although some groups have elevated the developmental rate to near $90 \%$ by using histone deacetylase mRNA, an accurate description of the developmental pathways in SCNT murine embryos is unreported [23].

Polo-like kinase 1 (Plk1) is also known as serine/ threonine-protein kinase 13 (STPK13) [12]. It is encoded by the
PLK1 gene in mouse chromosome 7 and human chromosome 16. $\mathrm{Plk} 1$ is considered a proto-oncogene because it is observed frequently in tumor cells [20]. A defect in Plk1 expression causes hindrance of cell growth via a pro-apoptotic pathway [4]. In somatic cells, Plk1 localizes with centrosomes in the interphase [18]. Plk1 regulates cytokinesis including centrosome and chromosome maturation [36], adhesion of kinetochoremicrotubules, and timing of mitotic division initiation [24]. During meiosis, Plk1 acts as an essential microtubuleassociated protein together with anaphase-promoting complex and CDC5 [31].

Many studies have demonstrated that Plk1 has a critical role in mitotic cell division in somatic cells and cancer cells $[9,29,30]$. Most recently, some studies have shown the importance of Plk1 in mammalian meiotic and early mitotic stage [16,27,39]. Spindle organization proteins, such as Plk1, also have critical roles in meiotic and mitotic divisions including chromosome segregation in the pre-implantation stage of mouse embryos. Compared with in vivo-fertilized embryos during early cleavage, abnormal chromosome segregation is 
reported to occur frequently in SCNT murine embryos [25]. Thus, the expression and localization patterns of Plk1 in SCNT murine embryos were investigated and compared with in vivo counterparts to demonstrate the correlation between Plk1 expression and poor development of SCNT murine embryos. Although, some studies have demonstrated that Plk1 is an essential factor in mammalian embryos, in SCNT murine embryos, the expression patterns of Plk1 have not been reported. Therefore, this study investigated the Plk1 expression patterns in SCNT murine embryos.

\section{Materials and Methods}

\section{Materials}

All organic and inorganic compounds were purchased from Sigma-Aldrich Korea (Korea).

\section{Animal use and ethical statement}

All metaphase II (MII) oocytes and donor cells were acquired from 6 to 8 weeks old C57BL6 X DBA2 F1-hybrid (B6D2F1) female mice (Orient Bio, Korea). Animal experiments were approved under the agreement guidelines of the Institutional Animal Care and Use Committee of Seoul National University (approval No. SNU-130123-5-5).

\section{Collection oocytes and preparation of donor cells}

The 7.5 IU of equine chorionic gonadotropin (eCG; Daesung Microbiology Labs, Korea) were introduced to female B6D2F1 mice by intraperitoneal injection for superovulation. Forty-eight hours later, 7.5 IU of human chorionic gonadotropin (hCG; Daesung Microbiology Labs) were injected into the mice. To obtain in vivo-fertilized embryos, two female mice were mated with a male mouse immediately after hCG injection. Oocytes and in vivo-fertilized embryos were collected $15 \mathrm{~h}$ after the hCG injection. Briefly, oviducts of mice were transferred to $2 \mathrm{~mL}$ TCM-199 with Earl's salts medium (TCM-washing) including $300 \mathrm{IU} / \mathrm{mL}$ of hyaluronidase to remove cumulus cells. Oocytes were recovered from torn ampullae. After 3 to 4 min of exposure to the hyaluronidase-containing TCM-washing medium, the cumulus-free oocytes were washed five times in Hepes-CZB medium (HCZB) before manipulation. The cumulus cells were suspended in a $10 \mu \mathrm{L}$ TCM-washing droplet mixed with $12 \%$ polyvinylpyrrolidone (PVP) for subsequent use as donor cells. Finally, the entire dish was covered with mineral oil.

\section{Enucleation}

Oocytes $(12-15)$ were set in a $10 \mu \mathrm{L}$ droplet of HCZB, including $10 \mu \mathrm{g} / \mathrm{mL} \mathrm{CB}$, and were then covered by mineral oil and kept in a $37^{\circ} \mathrm{C}$ operation heat chamber on a microscope stage. The zona pellucida of the oocyte was pierced by an enucleation pipette with several piezo pulses using a piezo-actuated micromanipulator (PMM-150FU; Prime Tech,
Japan). The diameter of the enucleation pipette was 6 to $8 \mu \mathrm{m}$. The MII chromosome-spindle complex was then removed via enucleation pipette (panel A in Fig. 1). The enucleated oocytes were transferred to $\mathrm{HCZB}$, washed three times, and kept for up to $30 \mathrm{~min}$ in KSOM medium.

\section{Nuclear injection}

The cumulus cells were collected by using $5 \mu \mathrm{m}$ diameter injection pipettes. The cells were aspirated in and out several times to accomplish membrane destruction. The zona pellucida was drilled out by an injection pipette and piezo pulses. Then, the donor cells in the pipette were injected into the enucleated oocytes by a single piezo pulse. After that SCNT, all of the reconstructed oocytes were washed three times in $\mathrm{HCZB}$ and kept for $10 \mathrm{~min}$ in room temperature $\mathrm{HCZB}$ to stabilize the oocytes. All injection protocols were undertaken at room temperature. After oocyte stabilization, reconstructed oocytes were kept in $\mathrm{KSOM}$ in a humidified $37^{\circ} \mathrm{C}$ incubator.

\section{Activation and culture}

The embryo culture medium was based on KSOM and CZB. Reconstructed SCNT oocytes and MII oocytes were kept separately in calcium-free CZB with $5 \mu \mathrm{g} / \mathrm{mL}$ cytochalasin B (CB) and $10 \mathrm{mM} \mathrm{SrCl}_{2}$ (ACZB) for oocyte activation. After $5 \mathrm{~h}$ $30 \mathrm{~min}$, activated oocytes were washed in HCZB five times and transferred in $\mathrm{KSOM}$ medium to a humidified $37^{\circ} \mathrm{C}$ incubator. The in vivo-fertilized embryos were similarly cultured in

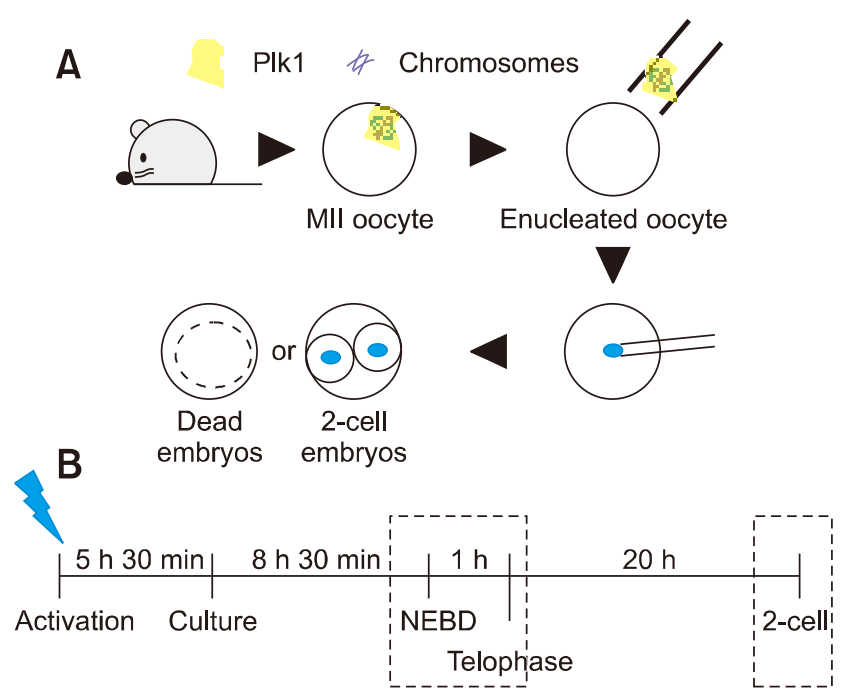

Fig. 1. Schematic representation of the experiments. (A) Illustration of the sequential experimental process. The blue dots are nuclei from the donor cell. (B) Timeline of the somatic cell nuclear transfer procedure. Immunofluorescence analysis was performed at the times within the boxes with dotted lines. The blue lightning bolt is at the time of activation treatment. Plk1, polo-like kinase 1; MII, metaphase II; NEBD, nuclear envelop breakdown. 
KSOM medium until analysis.

\section{Treatment of a Plk1 inhibitor, BI2536}

As Plk1 is essential for mitotic division in in vivo-derived embryos, embryos were treated with $2,4,10,20,100$, or 500 $\mathrm{nM}$ of BI2536 to investigate the optimal concentration required for Plk1 inhibition. The embryos used in the control group were cultured in KSOM medium with 1\% dimethyl sulfoxide. The embryos used in the experimental groups were placed in KSOM medium with the indicated concentrations of BI2536. All embryos were cultured in a $37^{\circ} \mathrm{C}$ humidified incubator for 30 $\mathrm{min}$. Immunofluorescence analysis was performed at the times in the boxes with dotted lines as described in panel B in Fig. 1.

\section{Immunofluorescence, live imaging and image analysis}

The reconstructed oocytes were fixed with $4 \%$ paraformaldehyde in phosphate-buffered saline (PBS) for 30 $\mathrm{min}$, then the oocytes were washed three times in PBS containing $0.5 \% \mathrm{PVP}$ and $0.1 \%$ Triton X-100 washing buffer. The oocytes were placed in PBS containing $0.25 \%$ Triton $\mathrm{X}-100$ for $4 \mathrm{~h}$ to make the membrane permeable and, then, incubated in PBS with $0.1 \%$ Triton X-100 and $1 \%$ BSA for

Table 1. First cleavage rates of in vivo-fertilized and somatic cell nuclear transfer (SCNT) murine embryos

\begin{tabular}{lc}
\hline \multicolumn{1}{c}{ Group } & No. of embryos cleaved $(\%)$ \\
\hline In vivo-fertilized $(\mathrm{n}=449)$ & $409(90.9 \pm 5.9)$ \\
SCNT $(\mathrm{n}=612)$ & $325(53.1 \pm 2.3)^{*}$ \\
\hline
\end{tabular}

Data are presented as mean \pm SD. ${ }^{*} p<0.05$. blocking for $2 \mathrm{~h}$ in a $37^{\circ} \mathrm{C}$ incubator. Plk1 was detected by rabbit polyclonal IgG antibodies (1:100; Santa Cruz Biotechnology, USA) and goat-anti-rabbit polyclonal IgG antibodies (1:500; Millipore, USA). DAPI staining was used to assess nuclear morphology. Confocal microscopy images were acquired by using an LSM 700 microscope (Zeiss, Germany). A JuLI Stage recorder (NanoEntek, Korea) was used to obtain live cell images. The confocal microscopy images were analyzed using Zen2 BLUE edition software (Zeiss).

\section{Statistical analysis}

All experiments were iterated three times at least. All percentage data obtained in this study are presented as mean \pm $\mathrm{SD}$ values. The embryonic development and first mitotic division data were analyzed by applying Student's $t$-test. A probability of $p<0.05$ was considered significant.

\section{Results}

\section{Comparison of first mitotic division efficiencies of SCNT murine embryos and in vivo-fertilized embryos}

The success rate for the first mitotic division of SCNT murine embryos $(53.1 \pm 2.3 \%)$ was significantly lower than that of in vivo-fertilized embryos $(90.9 \pm 5.9 \% ; p<0.05)$ (Table 1). The spindle and chromatin together with adjacent cytoplasm were removed by an enucleation pipette during the SCNT process, resulting in the removal of the greatest proportion of spindle-binding proteins including Plk1. The loss of Plk1 may have caused the low mitotic division rate of the SCNT murine embryos. Consequently, experiments were designed to analyze the expressions of Plk1 before and after mitosis in both SCNT and in vivo-fertilized murine embryos.
A

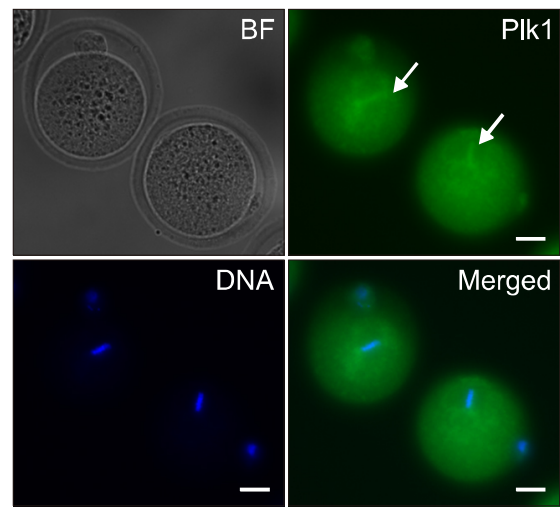

B





\section{C}

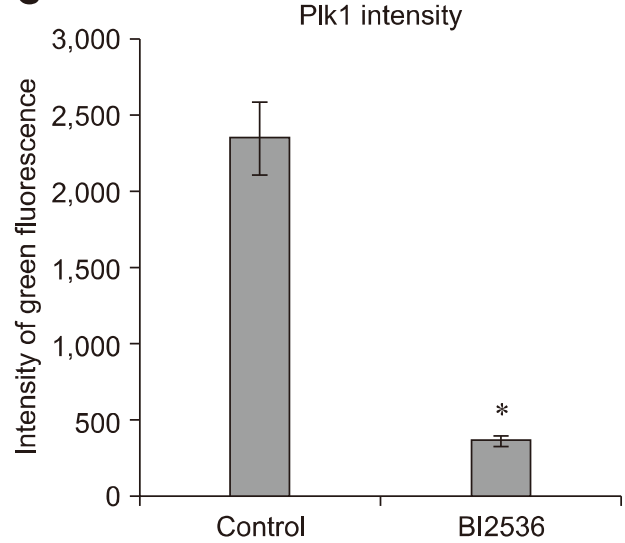

Fig. 2. Immunofluorescence expression of polo-like kinase 1 (Plk1) in mouse oocytes. (A) Plk1 (green) localized in the company of chromosomes (blue) in metaphase II oocytes (arrows). (B) Low intensity Plk1 in oocytes after enucleation. No chromosomes were detected in enucleated oocytes. (C) Quantization data for the fluorescence intensity of Plk1 in normal (control) and BI2536-treated oocytes. BI2536-treated oocytes show significantly higher fluorescence intensity. BF, bright field. ${ }^{*} p<0.05$. Scale bars $=20 \mu \mathrm{m}(\mathrm{A}$ and $\mathrm{B})$. 


\section{Intensity of Plk1 was significantly lower in enucleated oocytes than in MII oocytes}

The fluorescence intensity of Plk1 expression was measured by performing immunofluorescence analysis. In MII oocytes, marked fluorescence intensity of Plk1 was observed around the chromosomes and the spindle apparatus (panel A in Fig. 2; green). However, enucleated oocytes had low Plk1 fluorescence intensity as Plk1 was removed with the chromosomes during the enucleation process (panel B in Fig. 2). Quantization data obtained by confocal microscope analysis showed that the fluorescence intensity of Plk1 in MII oocytes was over five times higher than the intensity of Plk1 in enucleated oocytes (panel C in Fig. 2).

\section{Mitotic division of embryos was blocked by BI2536, a Plk1 inhibitor}

The images in panels $A-G$ in Fig. 3 show the morphology of embryos that were treated with different concentrations of BI2536. About $60 \%$ of the 2 nM BI2536-treated embryos and more than $90 \%$ of the untreated in vivo-fertilized embryos developed into 2-cell embryos, whereas all embryos treated with more than $4 \mathrm{nM}$ of BI2536 failed to attain 2-cell division (panel $\mathrm{H}$ in Fig. 3). Further, the groups of embryos that were treated with highs concentrations of BI2536, such as $100 \mathrm{nM}$ and $500 \mathrm{nM}$, were dead within $30 \mathrm{~min}$. The dead embryos showed membrane collapse and shrinkage (panels $F$ and $G$ in Fig. 3). Based on these results, $4 \mathrm{nM}$ of BI2536 was applied to block Plk1 in the next series of experiments. In addition, the effect of $\mathrm{BI} 2536$ was tested in parthenogenetic murine embryos. All parthenogenetic embryos that were treated with 4 $\mathrm{nM}$ of BI2536 did not develop to 2-cell embryos $(0.0 \pm 0.0 \%)$, while most untreated embryos developed to the 2-cell stage $(96.7 \pm 4.3 \%)$ (Table 2, Fig. 4). Taken together, the results above show that BI2536, a Plk1 inhibitor, causes blocking of mitotic
Table 2. First cleavage rates of BI2536-treated, and control parthenogenetic murine embryos

\begin{tabular}{lc}
\hline \multicolumn{1}{c}{ Group } & No. of embryos cleaved $(\%)$ \\
\hline Control $(\mathrm{n}=30)$ & $29(96.7 \pm 4.3)$ \\
Bl2536-treated $(\mathrm{n}=31)$ & $0(0.0 \pm 0.0)^{*}$ \\
\hline
\end{tabular}

Data are presented as mean $\pm \mathrm{SD} .{ }^{*} p<0.05$.

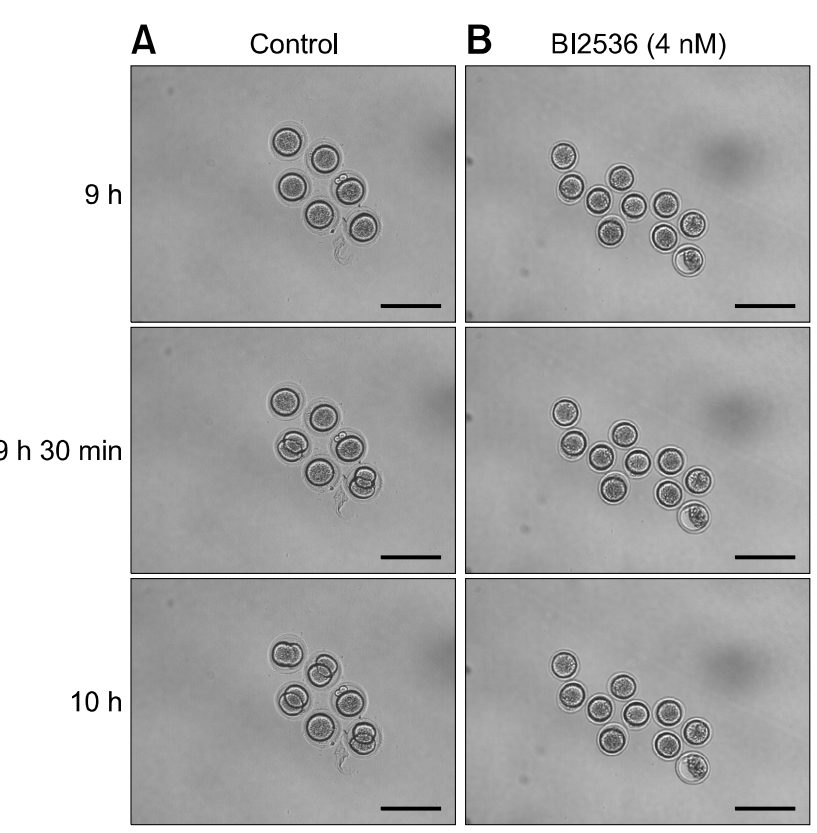

Fig. 4. Effect of BI2536 on the first mitotic division in parthenogenetic murine embryos. Embryos were cultured in KSOM medium with $1 \%$ of dimethyl sulfoxide (A) or with $4 \mathrm{nM}$ BI2536 (B). Scale bars $=100 \mu \mathrm{m}(\mathrm{A}$ and $\mathrm{B})$.
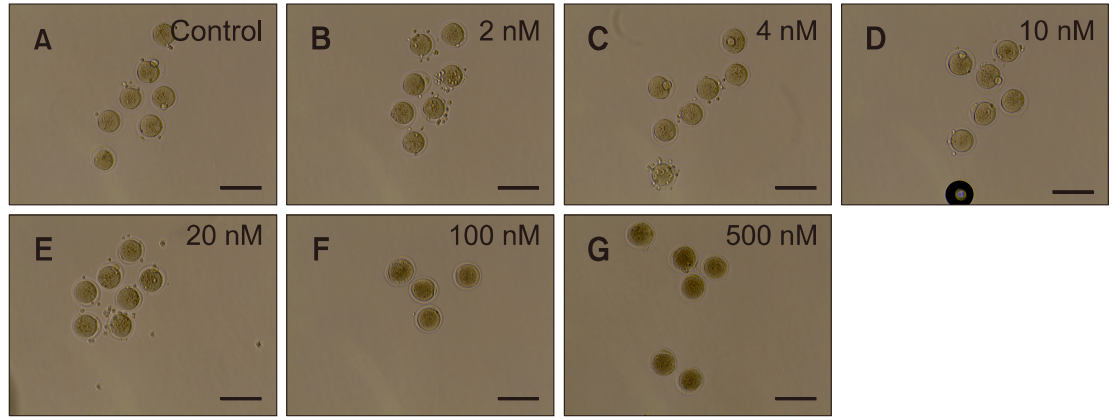

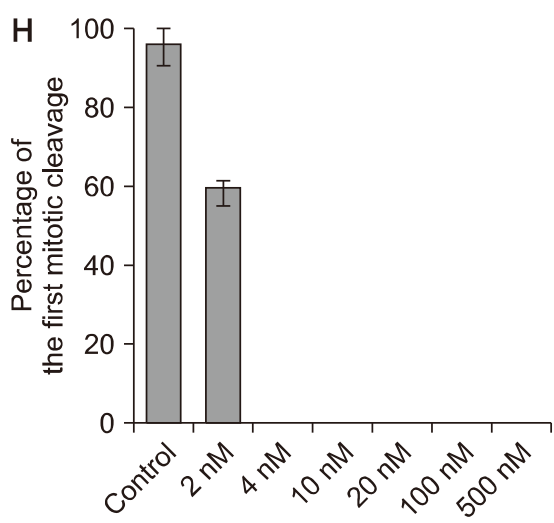

Fig. 3. Effect of BI2536 treatment in 1-cell embryos. (A) In vivo-fertilized embryos cultured in KSOM medium including $1 \%$ of dimethyl sulfoxide. (B-G) Embryos treated with BI2536 concentration from 2 to $500 \mathrm{nM}$. (H) Cleavage rate of embryos after BI2536 treatments at different concentrations. Scale bars $=100 \mu \mathrm{m}(\mathrm{A}-\mathrm{G})$. 
division in both in vivo-fertilized and parthenogenetic murine embryos. The experimental results confirm that Plk1 has a critical role in mitosis in early-stage mouse embryos. Therefore, in the following experiments, the focus was placed on the localization of Plk1 within the mouse embryo.

\section{Abnormal expression pattern of Plk1 was shown in SCNT murine embryos with developmental failure}

From fertilization to the 2-cell stage, the dual immunofluorescence labeling images showed that Plk1 was located around the nuclei in embryos that developed normally (panel A in Fig. 5). These results show that Plk1 gathers around the nuclear membrane from fertilization to the 2-cell stage under normal conditions. In addition, Plk1 expression was present on the nuclear membrane in 2-cell stage embryos. Interestingly, Plk1 exhibited a bridge-like morphology by being present between the two nuclei in 2-cell stage embryos with normal development. However, the SCNT murine embryos, which failed to reach the 2-cell developmental stage, presented two notable Plk1 results: ectopic Plk1 localization and low Plk1 expression. Among the in vivo embryos, 94\% showed normal Plk1 expression patterns with only $6 \%$ of those embryos showing a low Plk1 expression pattern. However, among the SCNT murine embryos, the low Plk1 expression pattern was twice that in the in vivo-fertilized group. In addition, the ectopic pattern, in which nuclei and Plk1 proteins were not co-located, was observed in the $35.2 \%$ of the SCNT murine embryos (panel B in Fig. 5, Table 3).

Next, to describe Plk1 expression in more detail, Plk1 and DNA were double-stained and monitored by using confocal
A
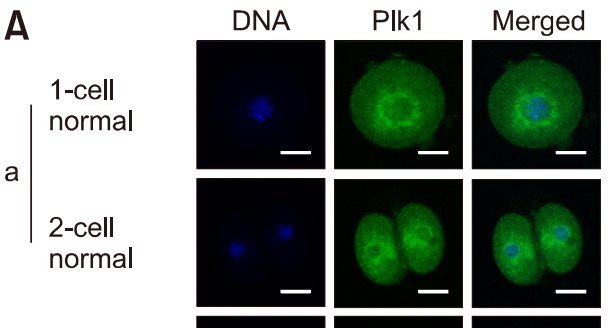

in vivo-fertilized
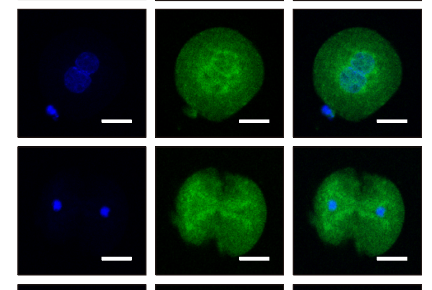
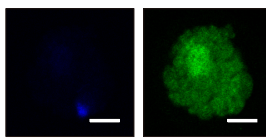

\begin{tabular}{l|l}
$c$ & $\begin{array}{l}\text { Ectopic } \\
\text { expression }\end{array}$
\end{tabular}
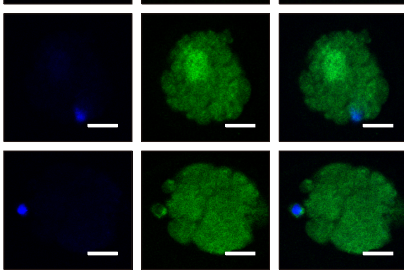

microscopy in both in vivo-fertilized and SCNT murine embryos. Images of 2-cell stage in vivo-fertilized embryos showed a bridge-like Plk1 expression morphology by Plk1 expression (panel A in Fig. 6). The Plk1 intensity levels in embryos with developmental failure were less than 1.0e04, while those in normally developed embryos were $2.0 \mathrm{e} 04$ and above, which is twice higher, than in developmental failure group. Based on those results, embryos with a Plk1 intensity value under 1.0e 04 were classified as low intensity. The SCNT 2-cell embryos that developed normally also exhibited a bridge-like Plk1 expression morphology (panel B in Fig. 6). However, compared to the normally developed embryos, the SCNT murine embryos that failed to develop to the 2-cell stage exhibited the two Plk1 expression pattern types: ectopic Plk1 expression (panel C in Fig. 6) and low Plk1 expression (panel D in Fig. 6). The Plk1 expression intensity was higher in the nuclear membrane boundary region than on the other side of the cytoplasm (panels

Table 3. Comparison of Plk1 expression patterns in somatic cell nuclear transfer (SCNT) and in vivo-fertilized embryos

\begin{tabular}{ccc}
\hline \multicolumn{1}{c}{ Group } & Plk1 expression pattern & No. of embryos (\%) \\
\hline \multirow{2}{*}{ In vivo-fertilized } & Normal & $94(94.0)$ \\
& Ectopic & $0(0.0)$ \\
\multirow{3}{*}{ SCNT } & Low & $6(6.0)$ \\
& Normal & $58(53.7)$ \\
& Ectopic & $38(35.2)$ \\
& Low & $12(11.1)$ \\
\hline
\end{tabular}

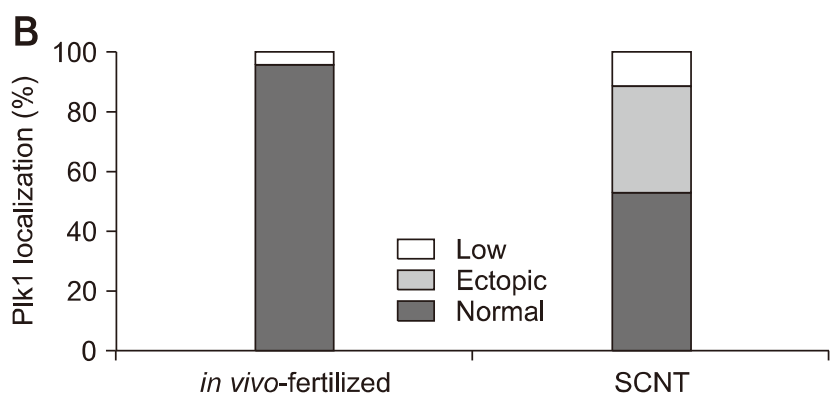

Fig. 5. Localization of polo-like kinase 1 (Plk1) in early-stage embryos. (A) Immunofluorescence images of Plk1 (green) and DNA (blue). Plk1 is located around the nucleus in normally developed in vivo-fertilized (a) and SCNT (b) murine embryos (b). The somatic cell nuclear transfer (SCNT) murine embryos which failed to undergo 2-cell division showed abnormal Plk1 expression patterns: ectopic expression (c) and low expression (d). (B) Percentages of Plk1 localization patterns in SCNT and in vivo-fertilized embryos. Scale bars $=20 \mu \mathrm{m}(\mathrm{A})$. 
A

in vivo-

fertilized;

2-cell normal
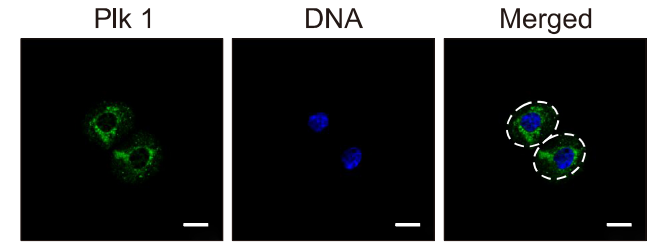

B

SCNT;

2-cell normal
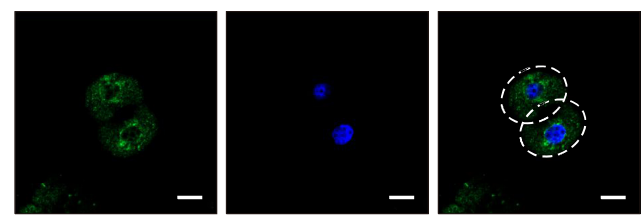

C

SCNT;

ectopic

expression
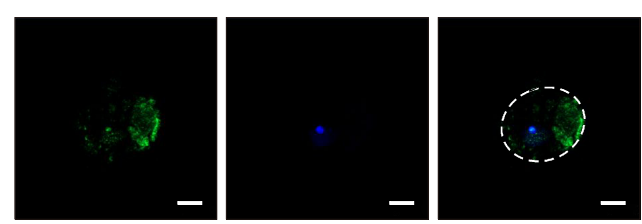

D

SCNT;

low expression
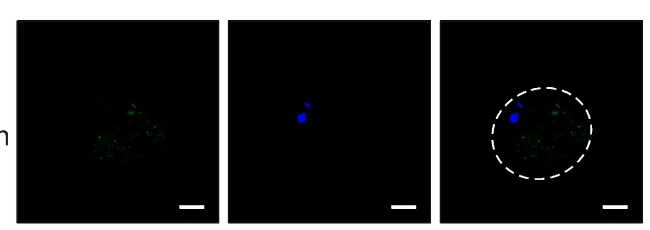

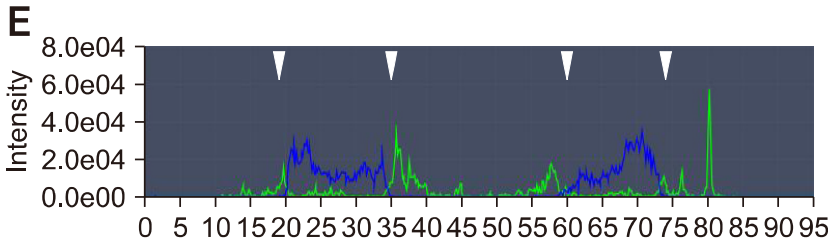

Distance $(\mu \mathrm{m})$

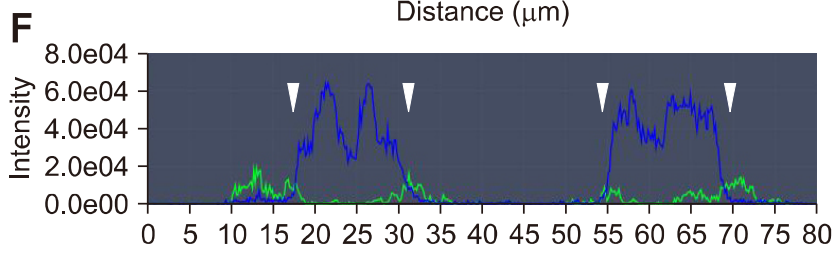

G Distance $(\mu \mathrm{m})$
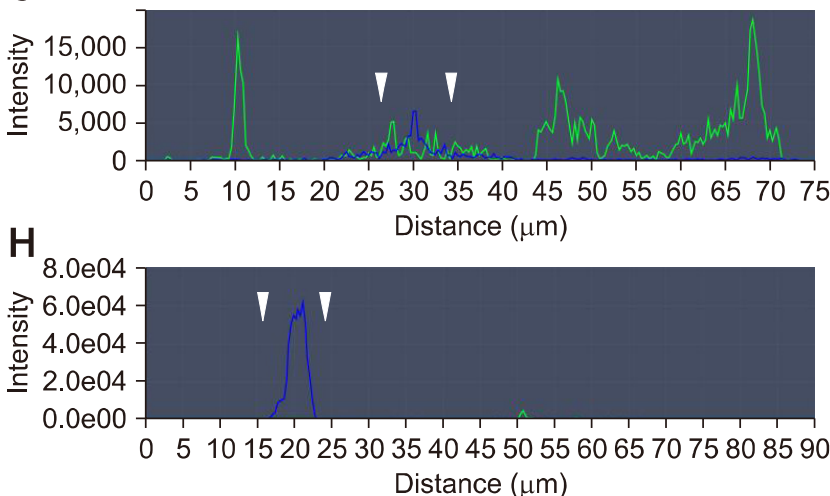

Fig. 6. Quantitative analysis of polo-like kinase 1 (Plk1) in somatic cell nuclear transfer (SCNT) and in vivo-fertilized embryos. (A-D) Immunofluorescence images of Plk1 and DNA stained with Plk1 antibodies (green) and DAPI (blue), respectively. (E-H) Graphs of immunofluorescence intensity values measured in the area of the dotted circles in Fig. 6 A-D. Plk1 (green) was located around the nuclear membrane (blue) in in vivo-fertilized (A and E) and SCNT (B and F) 2-cell embryos that developed normally. Plk1 expression concentrated on the nuclear membranes in in vivo-fertilized and SCNT murine embryo of normal development (arrowheads). (C and G) Ectopic expression of Plk1 in SCNT murine embryos that failed to develop. (D and H) The low PIk1 expression pattern in SCNT murine embryo that failed to develop. Scale bars $=20 \mu \mathrm{m}(\mathrm{A})$.

$\mathrm{E}$ and $\mathrm{F}$ in Fig. 6; arrowheads). In the group showing Plk1 ectopic expression, the expression of Plk1 was significantly lower in the nuclear membrane boundary (arrowheads) than on the other side of the cytoplasm (panel G in Fig. 6). Twelve percent of the SCNT murine embryos had a low-intensity Plk1 expression pattern (panel H in Fig. 6). Taken together, the Plk1 expression location in the embryos that developed to the 2-cell stage normally, including SCNT embryos, was around the nuclear membrane boundary in both 1-cell and 2-cell stage embryos. However, the Plk1 expression of the SCNT murine embryos that failed to develop showed both a low level of Plk1 expression and ectopic Plk1 expression.

\section{Discussion}

In previous studies, Plk1 has been shown to be an essential element in mitotic cell division [14]. However, cell division of embryos during development is different from that of somatic cells [26]. Recently, some studies have demonstrated that Plk1 is a critical protein in meiosis and at the embryo pre-implantation stage $[2,40]$. Mouse and primate SCNT procedures include an enucleation process that removes the MII spindle. This method results in the loss of chromosomes and spindle-binding proteins. However, oocytes and embryos before the 2-cell stage do not have an intact zygotic genome activation ability [34]. Accordingly, protein rescue of early-stage embryos depends on maternal mRNA. Therefore, early-stage SCNT murine embryos have an inadequate protein rescue ability for chromosomes and spindle-binding proteins. Hence, we focused on the effect of Plk1 loss during the development of SCNT murine embryos in this study.

First, our results confirmed that Plk1 was located together with the chromosomes in MII stage oocytes. Consequently, after enucleation, there was a low Plk1 expression in the enucleated oocytes. This result shows that Plk1 is removed with the chromosomes during the enucleation process. Next, the embryos were treated with BI2536, a Plk1 inhibitor, to determine whether BI2536 affects early mitotic division in 
mouse embryos. Although the $50 \%$ inhibitory concentration value of BI2536 is reported to be $0.83 \mathrm{nM}$ in human cancer cells [32], some research groups have used higher concentrations of BI2536 such as 100 to $500 \mathrm{nM}$ to inhibit mitosis $[1,19]$. In this study, BI2536 treatments over $100 \mathrm{nM}$ produced rapid apoptosis of embryos similar to results reported by another research group studying the toxicity of BI2536 [28]. In this study, $4 \mathrm{nM}$ of BI2536 was sufficient to block in vivo-fertilized and parthenogenetic embryos from reaching the 2-cell stage. Taken together, these results confirm that Plk1 is a crucial cytokinesis protein in mouse pre-implantation embryos.

For verification of the location and expression of Plk1, assessment of immunofluorescence assay results for Plk1 and DNA followed. It was observed that Plk1 was expressed around the nuclei in all of the normally developed embryos. However, the embryos that failed to reach the 2-cell stage exhibited two difference in Plk1 expression patterns; first, there was a low level of Plk1 expression in the embryo's cytoplasm and second, there was a pattern of ectopic Plk1 expression. In those embryos, the Plk1 was not co-located with the nucleus. Ectopic expression of Plk1 was only observed in the SCNT murine embryos that did not develop past the 2-cell stage. These results suggest that ectopic localization of Plk1 might be the result of removing Plk1 recruiting elements, such as Aurora family kinase, inner centromere protein, and survivin [33].

In conclusion, even though the accurate mechanism involved in SCNT murine embryo development remains incompletely described, the results of this study demonstrate that Plk1 has a critical role in the first mitotic division in mouse SCNT murine embryos. In particular, this study suggests the nuclear membrane boundary localization of Plk1 is crucial for successful development in SCNT murine embryos. These results provide a new insight to elucidating the molecular mechanisms in SCNT murine embryos.

\section{Acknowledgments}

This study was supported by a grant from the National Research Foundation of Korea (NRF-2016R1D1A1B03931864) and by the Technology Development Program (S2519744) funded by the Ministry of SMEs and Startups (Republic of Korea). The authors also thank Eura Roh for assisting in correcting the report's grammatical errors.

\section{Conflict of Interest}

The authors declare no conflicts of interest.

\section{References}

1. Baran V, Solc P, Kovarikova V, Rehak $\mathbf{P}$, Sutovsky $\mathbf{P}$. Polo-like kinase 1 is essential for the first mitotic division in the mouse embryo. Mol Reprod Dev 2013, 80, 522-534.

2. Bennabi I, Terret ME, Verhac MH. Meiotic spindle assembly and chromosome segregation in oocytes. J Cell Biol 2016, 215, 611-619.

3. Betthauser J, Forsberg E, Augenstein M, Childs L, Eilertsen K, Enos J, Forsythe T, Golueke P, Jurgella G, Koppang R, Lesmeister T, Mallon K, Mell G, Misica P, Pace M, Pfister-Genskow M, Strelchenko N, Voelker G, Watt S, Thompson S, Bishop M. Production of cloned pigs from in vitro systems. Nat Biotechnol 2000, 18, 1055-1059.

4. Bucur O, Stancu AL, Muraru MS, Melet A, Petrescu SM, Khosravi-Far R. PLK1 is a binding partner and a negative regulator of FOXO3 tumor suppressor. Discoveries (Craiova) 2014, 2, e16.

5. Bui HT, Seo HJ, Park MR, Park JY, Thuan NV, Wakayama T, Kim JH. Histone deacetylase inhibition improves activation of ribosomal RNA genes and embryonic nucleolar reprogramming in cloned mouse embryos. Biol Reprod 2011, 85, 1048-1056.

6. Byme JA, Pedersen DA, Clepper LL, Nelson M, Sanger WG, Gokhale S, Wolf DP, Mitalipov SM. Producing primate embryonic stem cells by somatic cell nuclear transfer. Nature 2007, 450, 497-502.

7. Campbell KH, McWhir J, Ritchie WA, Wilmut I. Sheep cloned by nuclear transfer from a cultured cell line. Nature 1996, 380, 64-66.

8. Chung YG, Eum JH, Lee JE, Shim SH, Sepilian V, Hong SW, Lee Y, Treff NR, Choi YH, Kimbrel EA, Dittman RE, Lanza R, Lee DR. Human somatic cell nuclear transfer using adult cells. Cell Stem Cell 2014, 14, 777-780.

9. Combes G, Alharbi I, Braga LG, Elowe S. Playing polo during mitosis: PLK1 takes the lead. Oncogene 2017, 36, 4819-4827.

10. Deuse T, Wang D, Stubbendorff M, Itagaki R, Grabosch A, Greaves LC, Alawi M, Grünewald A, Hu X, Hua X, Velden J, Reichenspumer H, Robbins RC, Jaenisch R, Weissman IL, Schrepfer S. SCNT-derived ESCs with mismatched mitochondria trigger an immune response in allogeneic hosts. Cell Stem Cell 2015, 16, 33-38.

11. Hai T, Hao J, Wang L, Jouneau A, Zhou Q. Pluripotency maintenance in mouse somatic cell nuclear transfer embryos and its improvement by treatment with the histone deacetylase inhibitor TSA. Cell Reprogram 2011, 13, 47-56.

12. Holtrich U, Wolf G, Bräuninger A, Kam T, Böhme B, Rübsamen-Waigmann $\mathbf{H}$, Strebhardt $\mathbf{K}$. Induction and down-regulation of PLK, a human serine/threonine kinase expressed in proliferating cells and tumors. Proc Natl Acad Sci U S A 1994, 91, 1736-1740.

13. Huang J, Zhang H, Yao J, Qin G, Wang F, Wang X, Luo A, Zheng Q, Cao C, Zhao J. BIX-01294 increases pig cloning efficiency by improving epigenetic reprogramming of somatic cell nuclei. Reproduction 2016, 151, 39-49.

14. Kang YH, Park JE, Yu LR, Soung NK, Yun SM, Bang JK, Seong YS, Yu H, Garfield S, Veenstra TD, Lee KS. Self-regulated Plk1 recruitment to kinetochores by the Plk1-PBIP1 interaction is critical for proper chromosome segregation. Mol Cell 2006, 24, 409-422.

15. Kato Y, Tani T, Sotomaru Y, Kurokawa K, Kato J, Doguchi H, Yasue H, Tsunoda Y. Eight calves cloned from somatic 
cells of a single adult. Science 1998, 282, 2095-2098.

16. Kim J, Ishiguro K, Nambu A, Akiyoshi B, Yokobayashi S, Kagami A, Ishiguro T, Pendas AM, Takeda N, Sakakibara Y, Kitajima TS, Tanno Y, Sakuno T, Watanabe Y. Meikin is a conserved regulator of meiosis-I-specific kinetochore function. Nature 2015, 517, 466-471.

17. Kishigami S, Wakayama S, Thuan NV, Ohta H, Mizutani E, Hikichi T, Bui HT, Balbach S, Ogura A, Boiani M, Wakayama T. Production of cloned mice by somatic cell nuclear transfer. Nat Protoc 2006, 1, 125-138.

18. Lee KS, Oh DY, Kang YH, Park JE. Self-regulated mechanism of Plk1 localization to kinetochores: lessons from the Plk1-PBIP1 interaction. Cell Div 2008, 3, 4.

19. Lénárt P, Petronczki M, Steegmaier M, Di Fiore B, Lipp JJ, Hoffmann M, Rettig WJ, Kraut N, Peters JM. The small-molecule inhibitor BI 2536 reveals novel insights into mitotic roles of polo-like kinase 1. Curr Biol 2007, 17, 304-315.

20. Li Z, Liu J, Li J, Kong Y, Sandusky G, Rao X, Liu Y, Wan J, Liu X. Polo-like kinase 1 (Plk1) overexpression enhances ionizing radiation-induced cancer formation in mice. J Biol Chem 2017, 292, 17461-17472.

21. Li Z, Sun X, Chen J, Liu X, Wisely SM, Zhou Q, Renard JP, Leno GH, Engelhardt JF. Cloned ferrets produced by somatic cell nuclear transfer. Dev Biol 2006, 293, 439-448.

22. Mallol A, Santaló J, Ibáñez E. Improved development of somatic cell cloned mouse embryos by vitamin $\mathrm{C}$ and latrunculin A. PLoS One 2015, 10, e0120033.

23. Matoba S, Liu Y, Lu F, Iwabuchi KA, Shen L, Inoue A, Zhang Y. Embryonic development following somatic cell nuclear transfer impeded by persisting histone methylation. Cell 2014, 159, 884-895.

24. Miyamoto T, Akutsu SN, Fukumitsu A, Morino H, Masatsuna Y, Hosoba K, Kawakami H, Yamamoto T, Shimizu K, Ohashi H, Matsuura S. PLK1-mediated phosphorylation of WDR62/MCPH2 ensures proper mitotic spindle orientation. Hum Mol Genet 2017, 26, 4429-4440.

25. Mizutani E, Yamagata K, Ono T, Akagi S, Geshi M, Wakayama T. Abnormal chromosome segregation at early cleavage is a major cause of the full-term developmental failure of mouse clones. Dev Biol 2012, 364, 56-65.

26. Niakan KK, Han J, Pedersen RA, Simon C, Pera RA. Human pre-implantation embryo development. Development 2012, 139, 829-841.

27. Otsuki J, Nagai Y, Chiba K. Association of spindle midzone particles with polo-like kinase 1 during meiosis in mouse and human oocytes. Reprod Biomed Online 2009, 18, 522-528.

28. Raab M, Kappel S, Krämer A, Sanhaji M, Matthess Y, Kurunci-Csacsko E, Calzada-Wack J, Rathkolb B, Rozman
J, Adler T, Busch DH, Esposito I, Fuchs H, Gailus-Durner V, Klingenspor M, Wolf E, Sänger N, Prinz F, Angelis MH, Seibler J, Yuan J, Bergmann M, Knecht R, Kreft B, Strebhardt K. Toxicity modelling of Plk1-targeted therapies in genetically engineered mice and cultured primary mammalian cells. Nat Commun 2011, 2, 395.

29. Schmucker S, Sumara I. Molecular dynamics of PLK1 during mitosis. Mol Cell Oncol 2014, 29, e954507.

30. Solc P, Kitajima TS, Yoshida S, Brzakova A, Kaido M, Baran V, Mayer A, Samalova P, Motlik J, Ellenberg J. Multiple requirements of PLK1 during mouse oocyte maturation. PLoS One 2015, 10, e0116783.

31. Soung NK, Park JE, Yu LR, Lee KH, Lee JM, Bang JK, Veenstra TD, Rhee K, Lee KS. Plk1-dependent and independent roles of an ODF2 splice variant, hCenexin1, at the centrosome of somatic cells. Dev Cell 2009, 16, 539-550.

32. Steegmaier M, Hoffmann M, Baum A, Lénárt P, Petronczki M, Krssák M, Gürtler U, Garin-Chesa P, Lieb S, Quant J, Grauert M, Adolf GR, Kraut N, Peters JM, Rettig WJ. BI 2536, a potent and selective inhibitor of polo-like kinase 1 , inhibits tumor growth in vivo. Curr Biol 2007, 17, 316-322.

33. Sun SC, Liu HL, Sun QY. Survivin regulates Plk1 localization to kinetochore in mouse oocyte meiosis. Biochem Biophys Res Commun 2012, 421, 797-800.

34. Svoboda P. Mammalian zygotic genome activation. Semin Cell Dev Biol 2018, 84, 118-126.

35. Tao J, Zhang Y, Zuo X, Hong R, Li H, Liu X, Huang W, Cao Z, Zhang Y. DOT1L inhibitor improves early development of porcine somatic cell nuclear transfer embryos. PLoS One 2017, 12, e0179436.

36. Vazquez-Martin A, Oliveras-Ferraros C, Cufí S, Menendez JA. Polo-like kinase 1 regulates activation of AMPactivated protein kinase (AMPK) at the mitotic apparatus. Cell Cycle 2011, 10, 1295-1302.

37. Wakayama T, Perry AC, Zuccotti M, Johnson KR, Yanagimachi R. Full-term development of mice from enucleated oocytes injected with cumulus cell nuclei. Nature 1998, 394, 369-374.

38. Wang YS, He X, Du Y, Su J, Gao M, Ma Y, Hua S, Quan F, Liu J, Zhang Y. Transgenic cattle produced by nuclear transfer of fetal fibroblasts carrying Ipr 1 gene at a specific locus. Theriogenology 2015, 84, 608-616.

39. Weng Ng WT, Shin JS, Roberts TL, Wang B, Lee CS. Molecular interactions of polo-like kinase 1 in human cancers. J Clin Pathol 2016, 69, 557-562.

40. Zhang Z, Chen C, Cui P, Liao Y, Yao L, Zhang Y, Rui R, Ju S. Plk1 inhibition leads to a failure of mitotic division during the first mitotic division in pig embryos. J Assist Reprod Genet 2017, 34, 399-407. 